\title{
PEMBELAJARAN MUFRODAT DENGAN METODE BERNYANYI DI GUBUK BACA KALPATARU DUSUN BENDRONG
}

\author{
Muhammad Holimi' ${ }^{1}$, Nur Faizah ${ }^{2)}$ \\ 1)Institut Agama Islam Sunan Kalijogo Malang \\ 1)halimi15@gmail.com, 1)F41zahnf@gmail.com
}

\begin{abstract}
Abstrak. Bahasa arab adalah salah satu Bahasa asing yang diajarkan di Lembagalembaga sekolah mulai dari sekolah dasar sampai perguruan tinggi. Tak hanya pada Lembaga-lembaga formal, dalam bimbingan belajar atau kelompok belajar juga memberikan pembelajaran Bahasa arab seperti halnya di Gubuk Baca Kalpataru Dusun Bendrong, KKN mahasiswa IAI Sunan Kalijogo Jabung menerapkan pembelajaran Bahasa arab mengenai pembelajaran mufrodat. Hal demikian dikarenakan salah satu keterampilan berbahasa yang harus dikuasai adalah keterampilan berbicara. Sehingga untuk terampil dalam berbicara Bahasa arab, maka seseorang harus menguasai banyak mufrodat terlebih dahulu.

Untuk mencapai keberhasilan dalam bimbingan belajar mufrodat Bahasa arab ini, maka dibutuhkan suatu metode yang menarik untuk memudahkan seorang siswa dalam menerima materi pembelajaran. Salah satu metode yang digunakan dalam bimbingan belajar mufrodat Bahasa arab di Gubuk Baca Kalpataru Dusun Bendrong adalah dengan metode bernyanyi.

Pembelajaran mufrodat dengan metode bernyanyi Bahasa arab ini dilakukan dengan memberikan mufrodat dengan tema tertertu, misalkan mufrodat tentang العدد (bilangan ata angka) maka anak-anak diberikan materi mufrodat tersebut. Setelah anak-anak memahami materi mufrodat, maka dilanjutkan dengan bernyanyi sesuai dengan materi mufrodat yang telah disampaikan. Dengan adanya metode ini diharapkan dapat memberikan solusi untuk mempermudah anak-anak dalam belajar mufrodat Bahasa arab dan juga menjadi daya tarik mereka untuk belajar Bahasa arab lebih lanjut.
\end{abstract}

Kata Kunci: Pembelajaran Mufrodat, Metode Bernyanyi, Gubuk Baca Kalpataru

Abstract. Arabic is one of the foreign languages taught in school institutions ranging from elementary school to college. Not only in formal institutions, in tutoring or study groups they also provide Arabic language learning as is the case in the Reading Gubuk Kalpataru Dusun Bendrong, IAI student KKN Sunan Kalijogo Jabung applies Arabic language learning regarding mufrodat learning. This is 
because one of the language skills that must be mastered is speaking skills. So to be skilled in speaking Arabic, one must master many mufrodat first.

To achieve success in this Arabic mufrodat tutoring, we need an interesting method to make it easier for a student to receive learning material. One of the methods used in tutoring Arabic mufrodat in the reading hut of Kalpataru, Bendrong Hamlet is the singing method.

Mufrodat learning with the Arabic singing method is done by giving mufrodat with a certain theme, for example, mufrodat about العدا (numbers or numbers), then the children are given the mufrodat material. After the children understand the mufrodat material, then proceed with singing according to the mufrodat material that has been delivered. With this method, it is hoped that it can provide a solution to make it easier for children to learn Arabic language and also be an attraction for them to learn Arabic further.

Keywords: Mufrodat Learning, Singing Method, Gubuk Baca Kalpataru

\section{PENDAHULUAN}

Bahasa adalah sebuah alat komunikasi atau penghubung antara anggota masyarakat yang terdiri dari individu-individu untuk menyatakan pikiran, perasaan, dan keinginannya. ${ }^{1}$ Sehingga setiap manusia tentunya membutuhkan alat komunikasi berupa bahasa sebagai interaksi dan alat bertutur dalam kehidupan bermasyarakat. Menurut 'Abd al-majid, Bahasa adalah kumpulan isyarat yang digunakan oleh orang-orang untuk mengungkapkan pikiran, perasaan, emosi, dan keinginan. ${ }^{2}$

Bahasa arab merupakan salah satu bahasa mayor di dunia yang dituturkan lebih dari 200.000.000 umat manusia. Definisi lain Bahasa Arab merupakan salah satu bahasa asing yang sejak dahulu dipelajari oleh para generasi muslim di dunia. Di Indonesia pun bahasa dipelajari sejak anak usia dini, karena mayoritas masyarakat beragama Islam, yang mana mereka memiliki kitab Al-Qur'an yang diturunkan dengan bahasaArab. ${ }^{3}$

Beberapa pendapat pakar mengenai pengertian bahasa Arab, diantaranya :

1Dhieni, Nurbiana. 2005. MetodePengembangan Bahasa, Jakarta: Universitas Terbuka. h.8.

${ }^{2}$ Acep Hermawan, Metodologi Pembelajaran Bahasa Arab, ed. Anang Solihin Wardan, keempat (Bandung, 2014). h. 9.

${ }^{3}$ Syaiful Mustafa, Strategi Pembelajaran Bahasa Arab Inovatif, (Malang: UIN MALIKI PRESS, 2011), hlm. 26. 
1) Syaikh Mustafa Al-Gulayayniy memberikan pengertian bahasa sebagai berikut.

$$
\text { اللغة العربية هي الكلمة التي يعبر بها العرب عن أغراضهم }
$$

"Bahasa Arab adalah kalimatyang dipergunakan bangsa Arab dalam mengutarakan maksud / tujuan mereka."

2) Ahmad Al-Hashimiy memberikan pengertian bahasa Arab sebagai berikut :

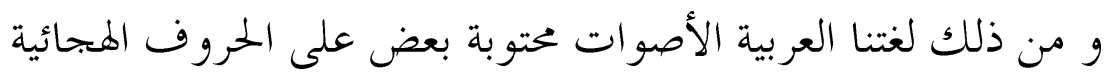

"Oleh sebab itu bahasa Arab adalah suara-suara yang mengandung sebagian huruf hijaiyyah".

Definisi bahasa Arab yang dikemukakan oleh dua orang pakar di atas, isi dan redaksinya saling berbeda tetapi maksud dan tujuannya sama. Oleh karena itu, penulis menarik kesimpulan bahwa bahasa Arab itu adalah alat yang berbentuk huruf hijaiyyah dipergunakan oleh orang Arab dalam berkomunikasi dan berinteraksi sosial baik secara lisan maupun tulisan.

Mempelajari Bahasa arab bukan hanya dari kalangan dewasa sebagai Bahasa pengantar Pendidikan atau bisnis, namun bagi anak-anak mempelajari Bahasa arab menjadi sangat penting terutama sebagai seorang muslim. ${ }^{4}$ Karena pada dasarnya bahasa arab merupakan bahasa mulia yang menjadi bahasa alquran, sehingga bekal untuk memperdalam al-quran tak lain adalah dengan mempelajari bahasa arab. Sebagaimana firman Alloh SWT dalam Q.S Yusuf: 2 agar mempelajari Bahasa arab sebagai berikut:

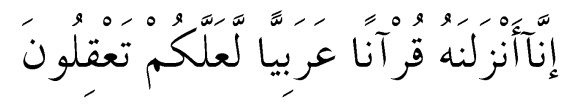

${ }^{4}$ Nur Hikmah Amalia and Nur Hidayat, "Penggunaan Media Teka-Teki Silang (Crossword Puzzle) Dalam Meningkatkan Kemampuan Baca Tulis Kosakata Bahasa Arab Peserta Didik Kelas III MI Ma'arif Giriloyo 1 Bantul," Al-Bidayah: Jurnal Pendidikan Dasar Islam 10, no. 1 (2018): 119-34. 
Artinya: "Sesungguhnya Kami menurunkan berupa Al-Qur'an berbahasa Arab, agar kamu mengerti"

Pembelajaran berasal dari kata dasar "ajar" yang berarti petunjuk yang diberikan kepada orang supaya diketahui (diturut) ditambah dengan awalan "pe" dan akhiran "an" menjadi "pembelajaran", yang bermakna proses, perbuatan, cara mengajar, atau mengajarkan sehingga peserta didik mau belajar. ${ }^{5}$ Sedangkan pembelajaran bahasa arab merupakan pembelajaran yang terdiri dari empat macam keterampilan atau biasa disebut dengan maharah yaitu, 1). Maharah istima' (keterampilan mendengar) 2). Maharah kalam (keterampilan berbicara) 3). Maharah qiroa'ah (keterampilan membaca), dan 4). Maharah kitabah (keterampilan menulis). ${ }^{6}$

Setiap keterampilan atau maharah itu erat kaitannya satu sama lain, biasanya ditempuh melalui hubungan yang teratur. Mulanya pada saat masih kecil seorang anak belajar menyimak bahasa, kemudian berbicara, yang setelahnya belajar membaca dan menulis. Materi awal yang akan diberikan pada pembelajaran bahasa arab adalah Mufrodat atau yang biasa disebut kosa kata. Semakin banyak kosa kata bahasa arab yang diperoleh oleh seseorang maka akan semakin terampil dalam bahasa arab.

kosakata adalah kata-kata yang merupakan perbendaharaan suatu bahasa. ${ }^{7}$ Definisi lain menyatakan bahwa kosakata adalah kekayaan kata yang dimiliki oleh suatu bahasa. ${ }^{8}$ Sedangkan Soedtijo memberikan batasan kosakata sebagai berikut: 1) Semua kata-kata yang terdapat dalam suatu bahasa, 2) Kata yang dipakai dalam suatu ilmu, 3) Kekayaan kata yang dimiliki oleh seorang pembicara, dan 4) Daftar kata yang

\footnotetext{
${ }^{5}$ M. Khalilullah, Media Pembelajaran Bahasa Arab, (Yogyakarta: Aswaja Pressindo, 2014), hlm. 3. ${ }^{6}$ UlinNuha, Metodologi Super EfektifPembelajaran Bahasa Arab (Yogyakarta: DIVA Press, 2012), 83

${ }^{7}$ Henry Guntur Tarigan. 1986. Menyimak Sebagai Suatu Keterampilan Berbahasa. Angkasa Bandung. h. 197.

${ }^{8}$ Burhan Nurgiyantoro. 2001. Penilaian dan Pengajaran Bahasa. Yogyakarta: BPFE. h. 213
} 
disusun kamus disertai penyelesaian singkat dan praktis. ${ }^{9}$ Karena Kosa kata merupakan salah satu unsur terpenting dalam bahasa termasuk bahasa Arab.10 Sehingga mufrodat atau kosa kata ini perlu diberdayakan guna menjadi dasar awal untuk belajar dalam bahasa arab. Semakin banyak kosa kata bahasa arab yang diperoleh oleh seseorang maka akan semakin terampil dalam bahasa arab.

Mempelajari Bahasa arab tidaklah sesulit yang dibayangkan tergantung bagaimana seorang pengajar dalam melakukan proses pembelajaran. Oleh karena itu dalam kegiatan belajar mengajar atau melakukan bimbingan belajar membutuhkan perangkat pembelajaran Salah satunya yang harus diterapkan adalah penggunaan metode yang sesuai dan semenarik mungkin. karena metode itu lebih penting dari materi. Materi apapun yang disampaikan, jika menggunakan metode yang benar, maka akan dapat diterima para siswa dengan baik. Sebaliknya materi yang telah dipersiapkan dengan matang, akan menjadi hampa tanpa metode yang baik. khususnya pada peserta didik usia anak-anak

Sama halnya kegiatan bimbingan belajar di Gubuk Baca Kalpataru Dusun Bendrong. Merupakan tempat bimbingan belajar khususnya bagi anak-anak di Dusun Bendrong yang disediakan oleh salah satu perangkat desa. Hal ini untuk menunjang kegiatan pembelajaran anak-anak di Dusun Bendrong karena adanya COVID-19 yang menjadikan efektivitasnya pembelajaran dalam sekolah formal. Selain itu banyak dari mereka yang sering mengatakan bosan kalau hanya belajar yang monoton seperti di sekolah apalagi dalam kondisi pandemi seperti ini. Melihat juga antusias anak-anak Gubuk Baca Kalpataru Dusun Bendrong dalam belajar Bahasa arab.

\footnotetext{
${ }^{9}$ Soedjito. 1992. Kosa kata Bahasa Indonesia. Jakarta: Gramedia Pustaka Utama. h. 1.

${ }^{10}$ Zahratun Fajriah, "Peningkatan Penguasaan Kosakata Bahasa Arab (Mufradat) Melalui Penggunaan Media Kartu Kata Bergambar," Jurnal Pendidikan Usia Dini 9, no. 1 (2015): 107-26.
} 
Sebagai alternatif pemecahan masalah tersebut, maka bimbingan belajar mufrodat Bahasa arab anak-anak Gubuk Baca Kalpataru Dusun Bendrong menerapkan metode bernyanyi. Menyanyi merupakan salah satu metode yang paling disukai anak-anak dalam pembelajaran karena cenderung aktif, ramai, riang dan gembira. Metode ini bertujuan untuk memudahkan anak-anak belajar mufrodat Bahasa arab. Karena dengan bernyanyi menjadikan emosi stabil dan berfikir jernih. sehingga anak-anak akan merasa senang dan tertarik untuk belajar Bahasa arab.

\section{METODE PENELITIAN}

\section{Pendekatan dan Jenis Penelitian}

Ditinjau dari jenis datanya pendekatan penelitian yang digunakan dalam penelitian ini adalah pendekatan kualitatif. Adapun yang dimaksud dengan penelitian kualitatif yaitu penelitian yang bermaksud untuk memahami fenomena tentang apa yang dialami oleh subjek penelitian secara holistik, dan dengan cara deskripsi dalam bentuk kata-kata dan bahasa, pada suatu konteks khusus yang alamiah dan dengan memanfaatkan berbagai metode ilmiah. ${ }^{11}$

Adapun jenis pendekatan penelitian ini adalah deskriptif. Penelitian deskriptif yaitu penelitian yang berusaha untuk menuturkan pemecahan masalah yang ada sekarang berdasarkan data-data.

Jenis penelitian deskriptif kualitatif yang digunakan pada penelitian ini dimaksudkan untuk memperoleh informasi mengenai bagaimana kegiatan bimbingan belajar bahasa arab anak-anak di Gubuk Baca Kalpataru Dusun Bendrong. Selain itu, dengan pendekatan kualitatif diharapkan dapat diungkapkan situasi dan permasalahan yang dihadapi dalam kegiatan bimbingan belajar.

\footnotetext{
11 Moleong, Lexy J. 2006. Metodologi Penelitian Kualitatif. Bandung : PT Remaja Rosdakarya. Hal. 6.
} 


\section{Teknik Pengambilan Data}

Dalam penelitian ini data yang dipakai adalah data primer dan data sekunder. Data primer data yang diperoleh langsung dari sumber utama atau bisa disebut dengan wawancara, yang berfungsi untuk mengetahui secara mendalam mengenai permasalahan yang akan diteliti secara mendalam, bagaimana pandangan subjek dalam penelitian terkait fenomena yang terjadi. Oleh karena itu dalam wawancara membutuhkan informan. Sedangkan data sekunder merupakan data yang dikumpulkan oleh peneliti dari sumber yang telah tersedia sehingga peneliti dapat disebut sebagai tangan kedua. ${ }^{12}$

Sehingga dapat disimpulkan Prosedur Pengumpulan Data pada penelitian ini adalah peneliti menggunakan beberapa metode dalam mengumpulkan data diantaranya:

1) Wawancara Yaitu percakapan dengan maksud tertentu, percakapan itu dilakukan oleh pihak, yaitu pewawancara: yang mengajukan pertanyaan, dan terwawancara yang memberikan jawaban atas pertanyaan itu. Maksud wawancara ini seperti ditegaskan oleh lincoln, antara lain mengkonstruksi mengenai orang, kejadian, organisasi, perasaan, motivasi, tuntutan, kepedulian dan lain-lain.

Ada dua jenis wawancara yaitu wawancara terstuktur dan wawancara tak terstuktur. Wawancara terstuktur adalah wawancara yang pewawancaranya menetapkan sendiri masalah dan pertanyaan-pertanyaan yang akan diajukan. Wawancara tak terstruktur merupakan wawancara yang berbeda dengan yang terstruktur. Cirinya kurang diinterupsi dan arbitrer.

12 Mulyadi. (2016). Sistem Informasi Akuntansi. Jakarta: Salemba Empat. Hl. 144. 
Sedangkan wawancara yang digunakan oleh peneliti dalam penelitian ini adalah wawancara terstruktur yang mana pertanyaan yang akan diajukan sudah ditentukan dan disusun oleh pewawancara sebelum melaksanakan wawancara.

2) Observasi, Metode observasi adalah suatu usaha sadar untuk mengumpulkan data yang dilakukan secara sistimatis, dengan prosedur yang terstandar. Metode Observasi yang digunakan dalam penelitian ini adalah observasi partisipan yang merupakan karakteristik interaksi sosial antara peneliti dengan subyek-subyek dalam lingkunganya.

Observasi ini di gunakan untuk melengkapi dan mengkaji hasil wawancara yang di berikan oleh informan yang mungkin belum menyeluruh dan belum mampu menggambarkan segala macam situasi atau bahkan melenceng dari realitas yang sebenarnya.

3) Dokumentasi, ini digunakan untuk memperoleh data-data pendukung, seperti nama-nama informan, serta dokumen-dokumen lain yang mendukung penelitian ini.

\section{HASIL DAN PEMBAHASAN}

\section{A. Gubuk Baca Kalpataru}

Kegiatan bimbingan belajar (bimbel) merupakan sebuah kegiatan yang berupaya membimbing dan menambah kegiatan belajar diluar kegiatan pembelajaran disekolah yang biasanya diikuti oleh anak-anak pada tingkat dasar. Bimbel ini sangat penting untuk diikuti oleh tingkat anak-anak karena masih dalam tahap kognitif. Selain itu, karena dampak adanya covid-19 yang mengakibatkan banyak sekolah-sekolah melakukan pembelajaran dalam jaringan yang menjadikan perlu adanya kegiatan belajar tambahan untuk menunjang kegiatan belajar anakanak. 
Berdasarkan wawancara yang kami lakukan kepada kepala desa Argosari menyatakan bahwa antusias anak-anak di Dusun Bendrong dalam belajar bahasa arab sangat baik. Diceritakan juga oleh beliau dua tahun yang lalu di Dusun Bendrong pernah dilakukan bimbingan belajar oleh KKN Mahasiswa lain, namun kegiatan itu tidak berlanjut karena tidak adanya tempat yang digunakan untuk bimbingan belajar. oleh karena itu beliau menginginkan adanya pembelajaran bahasa arab kembali dilakukan.

Wawancara kembali dilakukan kepada salah satu perangkat desa yang akrab dipanggil mbak Ayu mengenai tindak lanjut mengenai keinginan Bapak Kepala Desa mengenai bimbingan belajar bahasa arab. Akhirnya setelah dilakukan diskusi bersama, ditemukan solusi untuk diadakan tempat bimbingan belajar, dengan merenovasi tempat garasi dari rumah mbak ayu yang dijadikan tempat bimbingan belajar dan diberi nama dengan Gubuk Baca Kalpataru.

Dari pernyataan diatas Gubuk Baca Kalpataru Merupakan tempat bimbingan belajar khususnya bagi anak-anak di Dusun Bendrong yang disediakan oleh salah satu perangkat desa. Hal ini untuk menunjang kegiatan pembelajaran anak-anak di Dusun Bendrong karena adanya COVID-19 yang menjadikan efektivitasnya pembelajaran dalam sekolah formal.

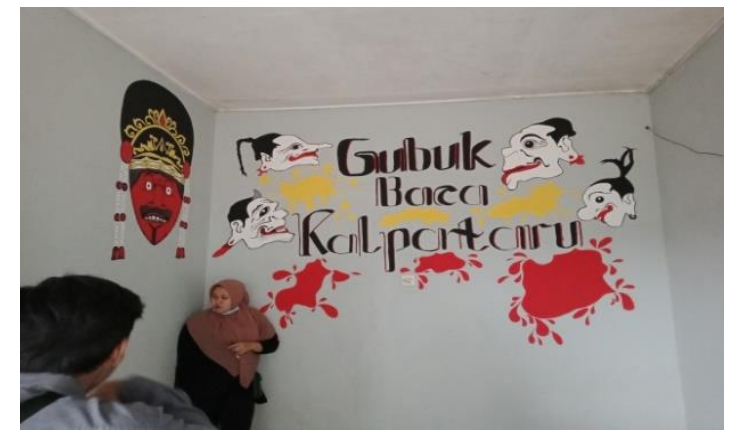

Gambar. 1 Gubuk Baca Kalpataru 


\section{B. Pengertian dan Tujuan Pembelajaran mufrodat}

Kosakata atau yang dalam bahasa arab disebut mufradāt, yaitu himpunan kata-kata atau khazanah kata yang diketahui oleh seseorang atau etinitas lain yang merupakan bagian dari bahasa tertentu. Dalam bahasa Inggris kosakata disebut dengan vocabulary. Kosakata juga dapat diartikan sebagai himpunan kata-kata yang dimengerti oleh orang tersebut dan kemungkinan akan digunakannya untuk menyusun kalimat baru. Selain itu kosakata merupakan salah satu dari tiga unsur bahasa yang harus dikuasai, kosakata ini digunakan dalam bahasa tulis maupun bahasa lisan dan merupakan salah satu alat untuk mengembangkan kemampuan berbahasa Arab seseorang. ${ }^{13}$

Selain itu menurut Al-Khauli dan Mahmud Ali, kosakata merupakan kumpulan kata-kata tertentu yang akan membentuk bahasa. Kosa kata adalah bagian terkecil dari bahasa yang sifatnya bebas. Pengertian ini membedakan antara kata dengan morfem. Morfem adalah satuan bahasa terkecil yang tidak bisa dibagi atas bagian bermakna yang lebih kecil yang maknanya relatif stabil. Maka kata terdiri dari morfem-morfem, misalnya kata mu'allim (معلم) dalam bahasa arab terdiri dari satu morfem. Sedangkan kata al-muallim (المعلم) mempunyai dua morfem yaitu الم dan deم . Adapun kata yang terdiri dari tiga morfem adalah kata yang terbentuk dari morfemmorfem di mana masing-masing morfem memiliki arti khusus. Misalnya kata al-

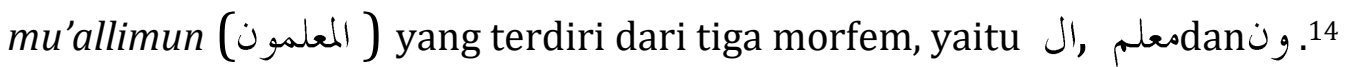

Dari beberapa pengertian diatas dapat disimpulkan kosa kata adalah salah satu unsur penting dalam suatu bahasa di samping unsur-unsur lainnya. Karena

\footnotetext{
13 Syaiful Mustofa. 2011. Strategi Pembelajaran Bahasa Arab Inovativ. Malang: UIN Maliki Press Malang. Hal: 76 14 Ibid..62.
} 
kualitas keterampilan berbahasa seseorang bergantung pada kualitas kosa kata yang dimilikinya. Semakin banyak kosa kata yang dimiliki, maka kemungkinan memiliki ketrampilan berbahasa lebih besar. Oleh karena itu, kosa kata merupakan suatu kebutuhan dasar dalam pengajaran bahasa kedua untuk dapat menguasai bahasa tersebut dengan baik.

Adapun tujuan umum pembelajaran kosakata (mufradāt) bahasa arab adalah sebagai berikut: (a) Untuk memperkenalkan kosakata baru kepada siswa, baik melalui bacaan maupun istima', (b) Untuk melatih siswa untuk dapat melafalkan kosakata itu dengan baik dan benar, karena pelafalan yang baik dan benar mengantarkan kepada kemahiran berbicara dan membaca secara baik dan benar, (c) Untuk memahami makna kosakata, baik secara denotasi atau leksikal maupun ketika digunakan dalam konteks kalimat tertentu, dan (d) Mampu mengapresiasi dan memfungsikan mufradāt itu dalam berekspresi lisan maupun tulisan sesuai dengan konteksnya. ${ }^{15}$

\section{Pengertian Metode Pembelajaran}

Metode pembelajaran (thariqah al-tadris) adalah tingkat perencanaan program yang bersifat menyeluruh yang berhubungan erat dengan langkah-langkah penyampaian materi pelajaran secara procedural, tidak saling bertentangan, dan tidak bertengtangan dengan pendekatan Metode adalah suatu jalan yang dilalui untuk mencapai suatu tujuan. ${ }^{16}$ Materi apapun yang disampaikan, jika menggunakan metode yang benar, maka akan dapat diterima para siswa dengan baik. Sebaliknya materi yang telah dipersiapkan dengan matang, akan menjadi hampa tanpa metode

\footnotetext{
15 Ibid..63.

16Ibid
} 
yang baik. Sama halnya Menurut Mahmud Yunus, metode itu lebih penting dari materi (الطريقة أهم من المادة).17

\section{Metode Pembelajaran Mufrodat}

Pada umumnya banyak sekali metode yang digunakan dalam pembelajaran mufrodat kepada siswa, diantaranya:

a) Memberikan contoh (namdzij)

Guru menjelaskan arti kosakata baru dengan memberi contoh, atau menunjukkan sebuah benda yang memiliki kesesuaian arti dengan kata baru yang dimaksud.

b) Dramatisasi (tamtsil al-ma'na)

Guru menjelaskan arti kosakata baru dengan melakukan praktek, atau mendramatisasi arti kata yang dimaksud. Seperti ketika menjelaskan kata kataba, sang guru lalu menggerakkan tangannya seperti orang menulis.

c) Bermain peran (la'b-l-dawr)

Guru menjelaskan arti kosakata baru dengan mengambil peran orang lain, atau meminta siswa berperan sesuai dengan yang diinginkan. Misalkan, guru berperan menjadi pasien yang sakit perut, lalu diperiksa seorang dokter.

d) Menyebutkan antonim (mutadladat)

Guru menjelaskan arti kosakata baru dengan cara menyebutkanlawan katanya, seperti menyebutkan kata barid untuk kata har. Gurudapat menjelaskan arti kosakata baru dengan kata lain yang berlawanan, asalkan kata tersebut sudah dimengerti siswa atau telah disampaikan sebelumnya.

e) Menyebutkan sinonim (mutaradifat)

Guru menjelaskan arti kosakata baru dengan cara menyebutkanpadanan katanya,

17Sahkholid Nasution, "Metode Konvensional Dan Inkonvensional Dalam Pembelajaran Bahasa Arab," JURNAL ILMIAH DIDAKTIKA: Media Ilmiah Pendidikan Dan Pengajaran 12, no. 2 (2012). 
seperti menjelaskan arti kata mawla dengan menyebutkan kata sayyid asalkan kata tersebut sedah dimengerti siswa atau telah disampaikan sebelumnya.

f) Memberikan asosiasi (tada'iy-l-ma'ani) Guru menjelaskan arti kosa kata baru dengan cara membuatkan asosiasi makna, maksudnya menjelaskan dengan menampilkan kata-kata lain yang mengacu pada makna yang diinginkan. Seperti menyebutkan kata zawj, zawjat, awlad, untuk menjelaskan arti kata ailah.

g) Menyebutkan asal-usul kata (musytaqat) Guru menjelaskan arti kosakata baru dengan menjelaskan asal-usul kata. Misalnya, ketika menjelaskan makna mashadirat guru dapatmenyebutkan asalusul kata tersebut dengan menyebutkan kata shadara, shadr, mashdar, dan seterusnya.

h) Menjelaskan maksudnya (al-murad biha) Guru menjelaskan arti kosakata baru dengan menerangkan maksudnya. Beberapa kosakata baru terkadang dapat dijelaskan artinya dengan memberikan uraian beberapa kalimat yang mengacu pada makna yang dimaksud.

i) Mengulang-ulang bacaan (takrir-l-qiraah) Guru menjelaskan arti kosakata baru dengan memimpin atau meminta siswa membaca kembali berulang-ulang kosakata baru dengan rangkaian kalimat yang ada dalam teks, sehingga sampai ditemukan makna yang terkandung sasuai konteks kalimatnya.

j) Mencari dalam kamus (taftisy-l-ma'ajim) Guru menjelaskan arti kosakata baru dengan mengajak bersama- sama atau sendirian memeriksa arti kosakata baru tersebut dalam kamus. Cara semacam ini lebih cocok untuk digunakan bagi siswa mutawashshithatau mutaqaddiim.

k) Menerjemahkan langsung (tarjamah fauriyyah) 
Guru menjelaskan arti kosakata baru dengan secara langsung menerjemahkannya ke dalam bahasa yang digunakan siswa (bahasa pertama). Cara ini hendaknya menjadi pilihan terakhir dalam menjelaskanmakna kosakata baru ${ }^{31}$

l) Penggunaan bahasa pengantar

Dalam menjelaskan arti mufradat pengajar memberikan kata-kata baru berbahasa Arab kemudian menerangkannya dengan bahasa pengantar,misalnya bahasa Inggris. Kemudian siswa diminta untuk mengulang- ulang kata-kata berbahasa Arab tersebut beserta artinya dengan bahasa Inggris secara bersamasama.

m) Mendengarkan serta menirukan

Dalam mengajarkan kosakata baru pengajar mengucapkan kosakata tersebut kemudian siswa menirukannya setelah pengajar selesai mengucapkan.

n) Meletakkan kata dalam kalimat Setelah mengajarkan kosakata baru, guru harus memperhatikan hal-hal sebagai berikut: mengajarkan pengucapannya, mengajarkan artinya, mengajarkan penulisannya, mengajarkan bacaannya, dan mengajarkan penggunaannya dalam kalimat

o) Permainan (game)

Pengajaran kosakata dengan game ini dapat menggunakan kartu, CD,tekateki/tebakan (imathah) dan juga bisa dengan permainan dengan menggunakan alat teknologi lainnya. 


\section{E. Pembelajaran Mufrodat Dengan Metode Bernyanyi}

Metode menyanyi secara sederhana dapat dimaknai sebagai metode pembelajaran yang menggunakan nyanyian sebagai wahana belajar anak. ${ }^{18}$ Model lagu ini merupakan pengembangan dari Accelerated Learning atau percepatan pembelajaran yang dianggap lebih efektif dan lebih cepat dibandingkan belajar secara konvensional, dikembangkan pada pertengahan 1970 berdasarkan kerja Dr. George Lazanov. Model ini menitikberatkan pada pemberdayaan siswa untuk belajar lebih cepat, efektif dan lebih menyenangkan, sehingga materi akan lebih bermakna dan daya ingatnya lebih kuat. Materi yang disuguhkan yaitu dengan menggabungkan musik atau lagu, seni dan warna sebagai fokus lingkungan fisik serta guru adalah teladan perilaku untuk menjamin suksesnya siswa.

\section{F. Langkah-Langkan Pembelajaran Mufrodat Dengan Metode Bernyanyi}

1. Pengajar memberikan materi mufrodat yang akan diajarkan. Misalnya materi mufrodat tentang bilangan dalam bahasa arab (العدد), hal ini bias dengan ditulis dipapan tulis atau dengan dibagikan kertas tulisan.

\section{a) العدد}

\begin{tabular}{|c|c|c|c|}
\hline $\begin{array}{c}\text { أربعة } \\
\text { Empat }\end{array}$ & $\begin{array}{l}\text { ثلاثة } \\
\text { tiga }\end{array}$ & $\begin{array}{r}\text { إثنان } \\
\text { dua }\end{array}$ & $\begin{array}{l}\text { واحد } \\
\text { Satu }\end{array}$ \\
\hline $\begin{array}{c}\text { delapan } \\
\text { delan }\end{array}$ & $\begin{array}{c}\text { سبعة } \\
\text { tujuh }\end{array}$ & $\begin{array}{c}\text { ستة } \\
\text { enam } \\
\end{array}$ & مخسة \\
\hline & $\begin{array}{c}\text { عشرة } \\
\text { sepuluh }\end{array}$ & $\begin{array}{c}\text { تسعة } \\
\text { sembilan }\end{array}$ & \\
\hline & صفر Dan & Itu angka nol & \\
\hline
\end{tabular}

18 Jasa Ungguh Muliawan. 2009. Manajemen Play Group dan Taman Kanak-Kanak. Yogyakarta: Diva Press. Hal. 257. 


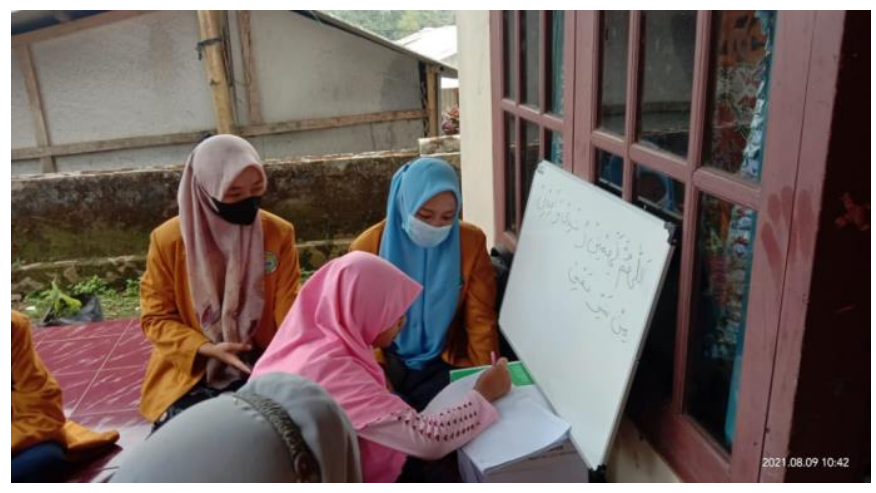

Gambar. 1 pengajar menuliskan materi mufrodat di papan tulis

2. Pengajar membacakan materi mufrodat (العدد), kepada para siswa, kurang lebih dibacakan sebanyak tiga kali,

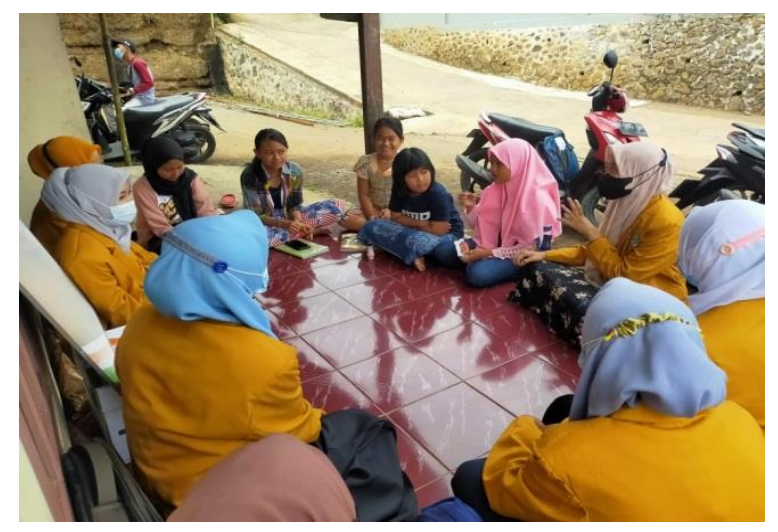

Gambar. 2 pengajar membacakann materi mufrodat kepada para siswa

3. Para siswa membaca ulang mufrodat yang telah dibacakan oleh pengajar. 


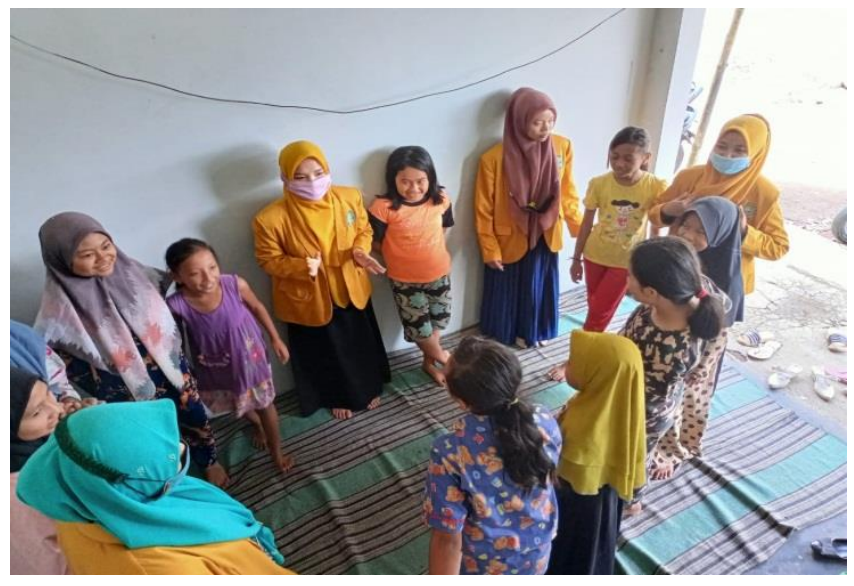

Gambar. 3 para siswa membaca ulang mufrodat

4. Setelah deperkirakan para siswa menguasai materi mufrodat atau bahkan sudah hafal , maka langkah selanjutnya adalah menunjukan irama lagu yang akan digunakan untuk bernyanyi.

العدد

Mari bernyanyi dengan mengikuti irama lagu anak kambing saya!

\begin{tabular}{|c|c|c|c|}
\hline $\begin{array}{c}\text { أربعة } \\
\text { empat }\end{array}$ & $\begin{array}{l}\text { ثلاثة } \\
\text { tiga }\end{array}$ & $\begin{array}{r}\text { dua } \\
\text { dut }\end{array}$ & $\begin{array}{l}\text { واحد } \\
\text { satu }\end{array}$ \\
\hline \multirow[t]{3}{*}{$\begin{array}{c}\text { delapan } \\
\text { delan }\end{array}$} & $\begin{array}{l}\text { سبعة } \\
\text { tujuh }\end{array}$ & $\begin{array}{c}\text { ستة } \\
\text { enam }\end{array}$ & خمسة \\
\hline & $\begin{array}{c}\text { عشرة } \\
\text { sepuluh }\end{array}$ & $\begin{array}{c}\text { تسعة } \\
\text { sembilan } \\
\end{array}$ & \\
\hline & صفر Dan & Itu angka nol & \\
\hline
\end{tabular}

5. Lakukan secara berulang-ulang. 


\section{PENUTUP}

Metode pembelajaran menggunakan nyanyian merupakan salah saatu metode pembelajaran yang dapat digunakan dalam pembelajaran Bahasa Arab khususnya pembelajaran mufrodat. Metode ini menitikberatkan pada pemberdayaan siswa untuk belajar lebih cepat, efektif dan lebih menyenangkan, sehingga daya ingat lebih kuat.

Banyak peneliti juga menyatakan penggunaan media nyanyian dapat membantu peserta didik lebih mudah untuk mengingat dan menghafal kosa kata di mana pembelajaran mufrodat dengan metode bernyanyi ini bertujuan untuk memermudah penyampaian materi kepada siswa, karena dengan menyanyi emosi siswa lebih stabil dan merasa tidak adanya beban dan siswa dengan mudah bisa menangkap materi apa yang telah diberikan oleh guru.

Tahap-tahap pembelajaran meliputi evaluasi penguasaan materi pada pertemuan sebelumnya beserta materi yang akan disampaikan. Kemudian menambah materi baru yang variatif agar siswa tidak merasa bosan dan lebih bersemangat dalam menambah materi. Untuk dapat mencapai tujuan pembelajaran dengan metode bernyanyi membutuhkan kreatifitas guru dan membutuhkan persiapan yang matang agar tujuan pembelajaran dapat dicapai sesuai dengan yang diharapkan. 


\section{DAFTAR PUSTAKA}

Amalia, Nur Hikmah and Nur Hidayat, "Penggunaan Media Teka-Teki Silang (Crossword Puzzle) Dalam Meningkatkan Kemampuan Baca Tulis Kosakata Bahasa Arab Peserta Didik Kelas III MI Ma'arif Giriloyo 1 Bantul," Al-Bidayah: Jurnal Pendidikan Dasar Islam 10, no. 1 (2018).

Fajriah, Zahratun. "Peningkatan Penguasaan Kosakata Bahasa Arab (Mufradat) Melalui Penggunaan Media Kartu Kata Bergambar," Jurnal Pendidikan Usia Dini 9, no. 1 (2015).

Hermawan, Acep. Metodologi Pembelajaran Bahasa Arab, ed. Anang Solihin Wardan, keempat (Bandung, 2014).

Lexy, Moleong J. 2006. Metodologi Penelitian Kualitatif. Bandung : PT Remaja Rosdakarya.

M. Khalilullah, Media Pembelajaran Bahasa Arab, (Yogyakarta: Aswaja Pressindo, 2014).

Muliawan, Jasa Ungguh. 2009. Manajemen Play Group dan Taman Kanak-Kanak. Yogyakarta: Diva Press.

Mulyadi. (2016). Sistem Informasi Akuntansi. Jakarta: Salemba Empat.

Mustafa, Syaiful. Strategi Pembelajaran Bahasa Arab Inovatif, (Malang: UIN MALIKI PRESS, 2011),

Mustofa, Syaiful. 2011. Strategi Pembelajaran Bahasa Arab Inovativ. Malang: UIN Maliki Press Malang.

Nasution, Sahkholid. "Metode Konvensional Dan Inkonvensional Dalam Pembelajaran Bahasa Arab," JURNAL ILMIAH DIDAKTIKA: Media Ilmiah Pendidikan Dan Pengajaran 12, no. 2 (2012).

Nuha, Ulin. Metodologi Super EfektifPembelajaran Bahasa Arab (Yogyakarta: DIVA Press, 2012).

Nurbiana, Dhieni. 2005. MetodePengembangan Bahasa, Jakarta: Universitas Terbuka..

Nurgiyantoro, Burhan. 2001. Penilaian dan Pengajaran Bahasa. Yogyakarta: BPFE.

Soedjito. 1992. Kosa kata Bahasa Indonesia. Jakarta: Gramedia Pustaka Utama.

Tarigan, Henry Guntur. 1986. Menyimak Sebagai Suatu Keterampilan Berbahasa. Angkasa Bandung. 